\title{
Municipal bonds as a means of accelerating local infrastructure investment
}

\author{
Francesca Romana Medda \\ Professor, Qaser Lab, University College London, London, UK \\ (corresponding author: f.medda@ucl.ac.uk)
}

\author{
Luca Cocconcelli \\ Data Analytics Manager, Qaser Lab, University College London, \\ London, UK
}

Even today, the 2007 financial crisis imposes negative impacts on the ability of local authorities to raise funds for capital investment, particularly for infrastructure. A fundamental need thus exists for municipalities and regional authorities worldwide to broaden their financial channels and explore flexible financial options. In the USA, municipal bonds represent the backbone of local public finance. Nearly three-quarters of core infrastructures in the USA are financed by municipal bonds, with about $\$ 400$ billion in issuances every year. However, the municipal bond market is not a rose without thorns. This paper examines different successful and unsuccessful experiences of local authority bond implementations for infrastructure investment. The limitations and advantages of more widespread use of bond issuance as a financial tool for infrastructure investments in the USA are examined. Next, the paper discusses how the problem of risk hinders investment, particularly in infrastructure. Thereafter, the paper enquires whether the example of collective solutions can become the financial cornerstone for infrastructure investment in a discussion of other European approaches, in particular the Swedish case under the mantle of the Nordic Local Government Funding Agencies. After describing effective strategies for local authorities to apply bond tools for infrastructure investments, policy recommendations are discussed.

\section{Introduction}

Infrastructure investments are often considered to have a dual role; not only do they spur economic growth, but also through their improvement and development, they can foster private sector initiatives and thus stimulate investment (Andersson, 2012; Ahfeldt and Feddersen, 2010; Baldwin et al., 2005). In Europe, the most significant share of public investments, approximately $65 \%$ of all EU investments, is realised by local authorities (FMDV, 2014). However, the economic crisis of 2008 compelled central governments to slash available funds earmarked for infrastructure investments. In 2009, European local authorities suffered a striking $55 \%$ reduction in their government grants in conjunction with a $61 \%$ reported decrease in revenue from the fiscal system. The most interesting point arising from these data is the claim by $37 \%$ of European local authorities that securing loans is problematic, and above all, they express alarm at their inability to raise long-term borrowing at cost-effective rates. As a consequence, the investment in infrastructure has decreased in more than $40 \%$ of local and regional governments in the EU (United Cities and Local Governments, 2013, 2017). A similar situation can be observed in the UK, where, in 2016, it was reported that local authorities had over $£ 85$ billion in outstanding debt and $£ 3$ billion in outstanding borrowing and refinancing (Cobley, 2016).

With the contraction of traditional sources of finance (local taxes, grants and subsidies), alternative resources or the adaptation of established financial mechanisms have come to the fore, of which two noteworthy examples are environmental taxes and the broadbased system of land value finance (Medda, 2012). In this context of alternative financial mechanisms, the issuance of bonds as a financial source for local authorities provides an innovative investment vehicle that has sustainability potential, particularly if bonds are then bundled under green or social responsibility impacts, as in the case of the Ile-de-France region in 2012 (Novethic, 2013).

Although the economic downturn has called attention to various intrinsic problems present in US and European municipal bond markets, the contraction of credit imposed by banks is also critical to the discussion of how local authorities can navigate risk during the process of implementing bonds and, importantly, towards forging a connection between local authority governance and infrastructure investment needs. Currently in Europe, the total share of bonds issued by local authorities is still small in relation to government bond issues, which encompass nearly $60 \%$ of the European bond market (Investing Bonds Europe, 2013). In response, the present paper asserts that the bond market has the potential to mobilise finance, particularly the much-needed longterm finance for infrastructure investments.

Against this background, the aim of the paper is to give an overview of the municipal bond market in order to shed light on how the financial crisis has directly affected the municipal bond market and to show how, going forward, bond financing can be an effective mechanism for infrastructure investments. Beginning in Section 2, the history and US experience of municipal bonds as the traditional form of bond issuance by local authorities for infrastructure investments is briefly described. In the USA, municipal bonds are the backbone of local public finance; the mature US market may thus be viewed as an exemplar in less experienced contexts. Thereafter, in Section 3, local authorities' bond markets and their risk exposure are examined. In this 
section, the perspective shifts to examine municipalities that act as borrowers or investors, not as bond issuers, in order to demonstrate how the prevailing inexperience of local authorities has sometimes exposed municipalities to loans with toxic clauses and investments with hidden risk. In Section 4, attention is given to the borrowing strategies of agencies specialising in local government funding and which therefore handle the issuance of bonds, as in the case of the Nordic Local Government Funding Agencies (NLFGA). The municipal bond market is indeed complicated, and as such, these discussion steps are best interpreted as interconnected features. Lastly, in Section 5, the paper reaches conclusions and recommendations drawn from lessons learnt, by focusing on municipal bond applications in relation to infrastructure investments.

\section{Municipal bonds: the US experience}

Local authorities, particularly in the USA, have always had difficulty raising finance from central governments for their infrastructure investments (Boarnet, 2014). Therefore, as soon as the first issuance of a municipal bond in New York was recorded in 1812, these bonds became the cornerstone of local finance and investment (Chen et al., 2013). Already by 1844, municipal bond issues dedicated particularly to critical infrastructures were worth above $\$ 25$ million. In 2013 , there were US $\$ 3.7$ trillion in municipal bonds outstanding, and every year, approximately US\$400 billion is issued (Sifma, 2012).
A municipal bond can be defined as an interest-bearing debt financial product that stipulates an agreement between an investor and a local authority, the issuer of the bond. More specifically, general obligation (GO) bonds are backed by the capacity of the local authority to levy and raise taxes, whereas revenue bonds are issued for a specific project through which revenues are generated by the fees and charges that the project can produce (Bailey et al., 2009; Feldstein and Fabozzi, 2008).

One of the main attractive characteristics of US municipal bonds for investors is that interest payments are usually exempt from income tax, and only capital gains and losses are subject to taxation (Kalotay, 2014). The tax exemption feature of the US municipal bond market is, however, often only applicable in their own states or municipalities, and this circumstance has contributed to the fragmentation of the market. As observed by Green et al. (2007), the municipal bond market suffers many drawbacks because it is fragmented, opaque and illiquid. In fact, of the approximately US $\$ 4$ trillion in municipal bond value, most bonds are small issue and tend to trade infrequently. As depicted in Figure 1, in 2012, the total number of new issues was 15458 , with over $60 \%$ under US\$10 million.

Data provided by the Securities Industries and Financial Markets Association (Sifma, 2017) in Figure 2 show how nearly 50\% of municipal bonds are held by individuals who are indeed more

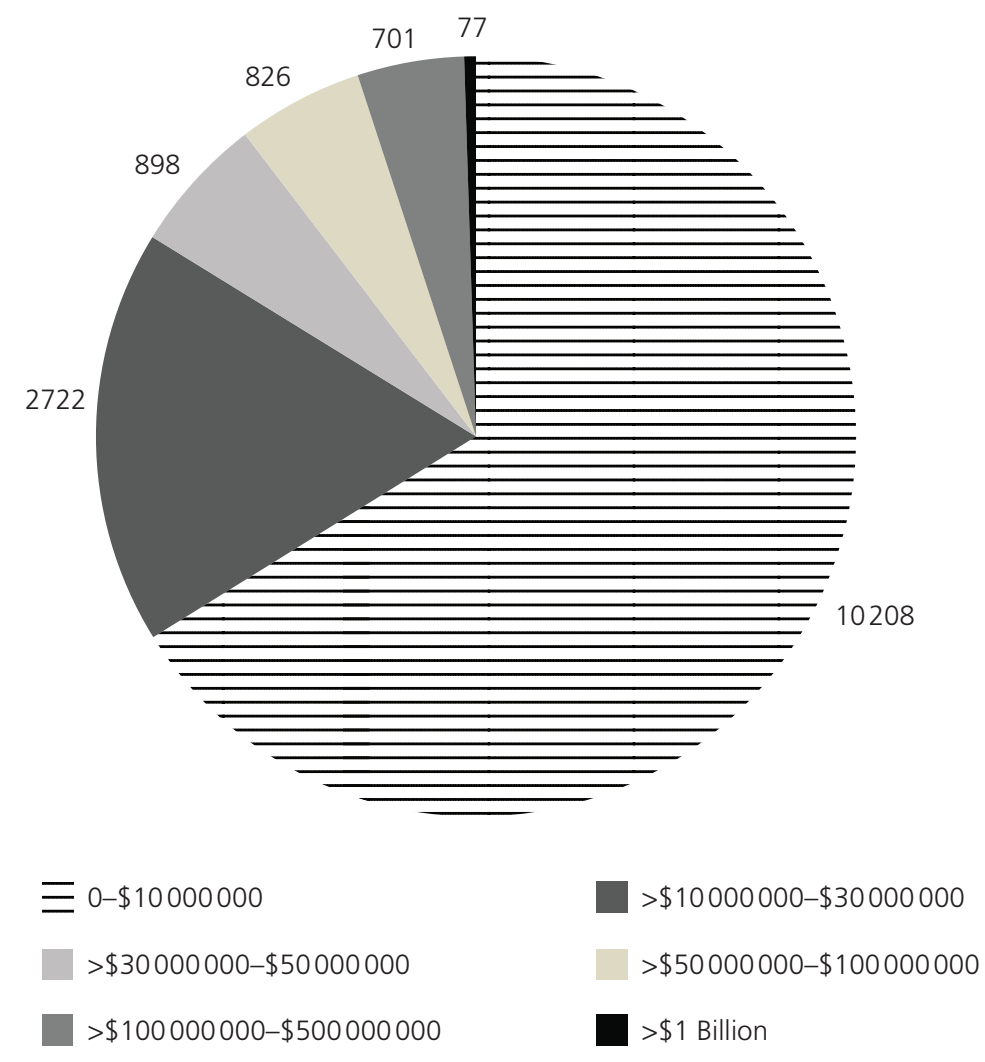

Figure 1. New issuance by size: January 2012-December 2012 


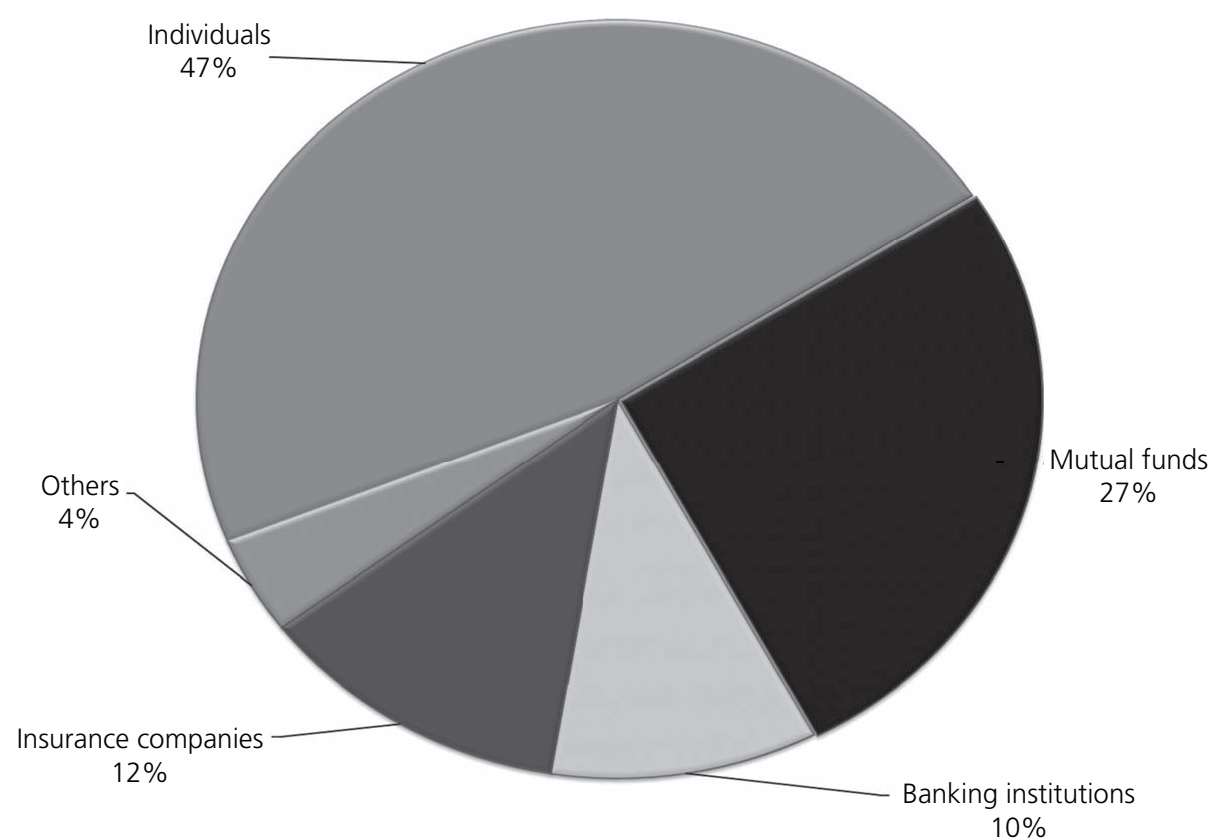

Figure 2. Holders of US municipal securities in 2012

likely to hold onto them until maturity, resulting in a market where bonds are traded infrequently.

After the financial crisis, the USA implemented several reforms, such as the Recovery and Reinvestment Act of 2009, which imposed different restrictions 'including volume caps by state, for certain housing and other private activity bonds' (Sifma, 2012: p. 13). Nevertheless, the availability of different types of municipal bonds, such as GO against revenue bonds, and serial issue against term issue bonds, makes municipal bonds particularly well suited for investments in infrastructure - which usually require capital-intensive and long-term investment. Infrastructure investments are often financed through GO bonds, given that 'they are securities to which the municipalities commit their full faith credit and taxing power; in the past, market analysts considered general obligation bonds the safest for investors, although that may be changing in a more distressed economy' (Berkooz, 2014: p. 26).

When comparing the total outstanding of GO and revenue bonds, one can notice in Figure 3 that in 2007, there were nearly US\$300 billion outstanding revenue bonds, whereas GO bonds amounted to only US $\$ 130$ billion that same year. This trend between the two types of bond, as shown in the figure, continued throughout the economic crisis and into the initial recovery in 2012.

Given the characteristics of revenue and general bonds, and, in particular, the fact that general bonds have a larger revenue base (i.e. taxpayers) than revenue bonds (i.e. users of a toll road), revenue bonds are more likely to be vulnerable to default. The default risk is generally reflected in the type of project, and specifically, the type of infrastructure investment and credit quality of local authorities/municipalities. Nonetheless, Moody's (2017: p. 25) has recently reported that 'the median rating for US municipal credits at the end of 2016 was high'.

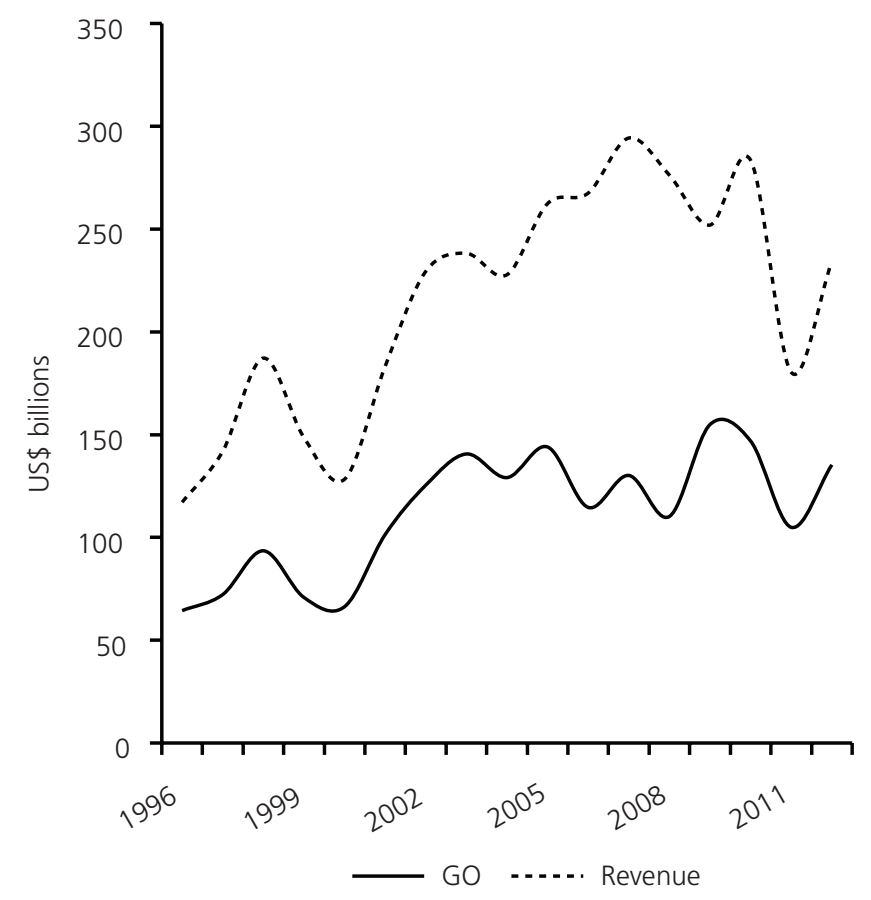

Figure 3. Total, GO bonds and revenue bonds and outstanding 
Moody's positive observation aside, most financial analysts agree that the US municipal bond market has changed over the past decade. After the 2008 financial crisis, municipalities worked to rebalance and stabilise operations by cutting costs, raising revenues and reshaping reserves as tax bases recovered. However, changes are still necessary. For instance, the subprime housing crisis of 2008 brought to light the cases of various financial products such as mortgage-backed securities, where the assigned rates were imprecise; this finding certainly put a strain on municipal bond markets, so much so that some rating agencies were blamed for wrongly assessing the risks of municipal bonds and the subsequent increase in the cost of borrowing for infrastructure (Edwards, 2013). In response to this criticism, in 2010, Moody's implemented a recalibration of municipal bond issues. However, as Richard Ciccarone (2010) from McDonnell Investment foresaw, the problems that are lurking on the horizon are likely to impose liabilities well beyond what governments have been facing in prior years.

The problematic past of the US municipal bond market means that the use of municipal bonds to finance infrastructure investment is more complicated than ever today, particularly for certain types of investment. Although infrastructure investments are capital intensive, some infrastructures such as energy require less upfront investment when the significant costs incurred over time for their operation (e.g. fuel) are considered. Conversely, transport infrastructure usually necessitates major upfront investment. The differences in the type of infrastructure investment are therefore reflected in the cost of capital, the interest level and the assessment of risk and thus strongly obstruct the capacity for municipal bonds to be implemented effectively to finance new technologies; these aspects are significant, particularly for sustainable infrastructure investments such as green energy infrastructure. In this case, it may be preferable to seek low-cost debt financing in order to facilitate and support environmental policy.

Indeed, to overcome the hurdle of the high cost of finance for sustainable infrastructure investment, US municipalities may learn from international examples, such as Germany (KfW Bank) and Britain (British Green Investment Bank), which have introduced different programmes to improve access to capital, lower financing costs and foster private investment through the reduction of taxpayer risk. In the context of bond issuance in the USA, an interesting case is the Connecticut Clean Energy Finance and Investment Authority (Cefia). Established in 2011, by 2012, Cefia was authorised to issue up to US\$50 million in municipal bonds to support renewable energy investments (Appleson et al., 2012). In this example, the issuance of the municipal bond has received the full backing and commitment of the state of Connecticut and provides a viable and stable alternative to the subsidy/incentive and grant-based programmes common to infrastructure investments. Above all, it demonstrates an example of best practice and a way forward in the development of new financial municipal bond products which, as Cefia professes, will allow citizens to invest in a green future (McCarthy and Hansen, 2013). Along the same lines in the USA is the Building and Renewing Infrastructure for Development and Growth in Employment (Bridge) Act (Infrastructure USA, 2017), which aims to establish the Infrastructure Financing Authority to assist US states and municipalities in leveraging private funds for large infrastructure projects (Decker, 2017).

\section{Infrastructure investment and investment risk}

As previously noted, the municipal bond market did not emerge unscathed from the financial crisis, and, "the once-comfortable aphorism that "munis don't default", is no longer credible, although default rates remain low' (Moody's, 2017: p. 175). Liu (2012) has argued that the probability of default is a primary proxy for assessing the credit riskiness of an investment. The Federal Reserve Bank of New York reported in 2012 that 2521 defaults of municipal bonds had occurred between 1970 and 2011, notwithstanding that a large share were in the unrated market. Certainly, long-term bonds generally carry more credit risk than short-term bonds (Allen, 2001), but GO bonds usually have very low default risk because the same local authorities that pledge their credit are also responsible for levying taxes and repaying the loan with tax revenue, whereas revenue bonds are more susceptible to default risk because the authorities can fail to meet their repayment loan obligations; this is an important consideration given that over the last two decades in the USA, for example, revenue bonds constituted more than $60 \%$ of the total bond issued by local authorities (Sifma, 2017).

Distinguishing between the types of infrastructure is another important discriminative factor when deciding whether municipal bonds (compared to other financial tools) are best suited as financial mechanisms. Core infrastructures that supply essential operations include main highways, metro systems, sewerage, water and electricity utilities because they are highly likely to generate revenue and would therefore incur low default risk. However, the so-called non-essential infrastructures, such as alternative rural road networks and public water facilities, to name two, are more vulnerable to the risk of default. For instance, in the case of Chesapeake City, Maryland, a revenue bond was issued for the investment on the toll road 168 Chesapeake Expressway. The toll revenue bond was rated to be lower than the city's general bonds, confirming that the type of project strongly influences the bond rating exercise.

In respect of the differences in the risk exposure of bonds issued by local authorities, and in order to increase their creditworthiness, guarantees have been introduced, particularly through monoline insurance. Monoline insurance companies are privately owned companies that act as credit enhancers for local authorities in their aim to reduce borrowing costs. In the USA, by 2002, more than $35 \%$ of municipal debt was insured by monoline companies, rising to nearly $50 \%$ in 2007 , just 5 years later (Figure 4). In 2006, over US $\$ 450$ billion municipal bonds were insured, but between 2007 


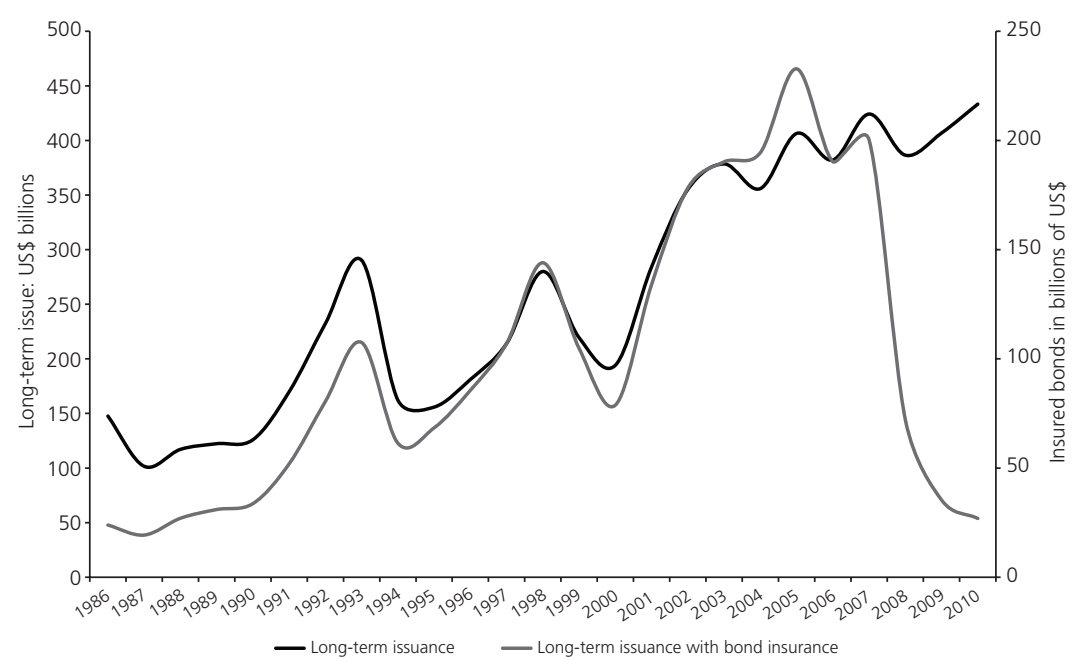

Figure 4. Long-term municipal bond issues insured

and 2009, the monoline insurance industry was hobbled by the economic crisis, primarily due to poor risk management in their investment activity and applications of opaque derivative insurance. When the crisis broke inside the financial market in late 2007, monoline insurers were inundated with claims to cover the losses on mortgage derivatives, which as it turned out, they were unable to cover. The result was devastating; the number of insured municipal bonds plummeted in 2009 from US $\$ 450$ billion to US\$50 billion.

At this point in the discussion on municipal bonds and more generally on infrastructure investments, it is also worth examining the role of the banking sector. The global and interconnected nature of the financial system has meant that the crisis, and the role of banking, has impacted forcefully on local authority finance activity, in, for example, the significant direct losses, which occurred in the UK due to the bankruptcy of the Icelandic banks; British local authorities lost over $€ 1$ billion. The debacle of the Dexia Bank is, nevertheless, for all intents and purposes, an instructive case.

Dexia was mainly a provider of loans for local authorities in France, Belgium and Luxembourg, but by 2008, it was one of the world's largest lenders to local authorities with assets at nearly $€ 6 \cdot 5$ billion. According to France's Prime Minister Francois Fillon, 'it was in 2000 that the most serious decision was taken, the one that brought about Dexia's most serious difficulties: the acquisition of an American monoline' (France in the United Kingdom, 2012). However, this problematic acquisition was added onto the pile of more than $€ 100$ billion of 'toxic' assets, which included subprime property bonds in Greece, Portugal and Ireland. The New York Times put it succinctly in 2011 as 'it is like using public money to support your local casino' (Morgenson and Story, 2011: p. A1). Other of Dexia's complex financial products related directly to municipal bonds, such as variable rate demand notes, which were grounded on wrong-way bets on interest rates. In Europe, many local authorities had been 'tricked' into taking out complex loans
(Blenkinsop and Laurent, 2011). These toxic loans had been presented to local authorities as fixed-interest-rate products pegged to the Euro-Swiss Franc exchange rate, but as the higher rates kicked in, local authorities saw borrowing rates rise from 4 to $15 \%$ and soar as high as 24\% (Assemblée Nationale, 2011).

Similar cases were taken to court against different financial institutions across other European cities, where, in 2009, the total amount of borrowing by all municipalities was $€ 36$ billion. For instance, in Italy, in 2011, more than 20 criminal investigations were underway (in Milan, Turin, Pisa, Verona, Carrara, Teramo, Fermo, Genoa, Florence, Pistoia, Biella, Benevento, Reggio Calabria and Palermo). Every one of these cases was linked to mis-selling - that is, they used public money to acquire derivative and complex financial products.

Following on the heels of the financial crisis, and in order to mitigate the negative impacts stemming from the international banking system, international regulations were also proposed. The new insurance regulation Solvency II, which would replace Solvency I in January 2014, was formulated to reduce the risk of firm bankruptcy, protect policyholders and prevent future market disruptions (FSA, 2012). However, this new insurance regime may not generate the desired effect of increasing investments in infrastructure. Pension funds may prefer to invest in infrastructures that are already in operation in order to avoid the large sunk costs of newly developed infrastructures. However, given the fact that infrastructure assets face the same capital charges as other assets, it unequivocally proves that regulatory authorities do not yet recognise that lower risk is a characteristic of infrastructure fund investments.

Basel III is the other important international regulatory response to the economic crisis; its aim is to enhance 'the regulatory framework for capital and introduce a new definition of capital to increase both the quantity and the quality of the regulatory capital 
base' (BIS, 2010: p. 2). Under this new regulation, for the same amount of debt that banks gave before the economic downturn, banks now have to allocate two to three times more capital. The upshot here is that banks need to charge more for their activity, and as a result, long-term debt such as infrastructure will be more affected than short-term debt (Inspiratia, 2010). Basel III also introduces stricter rules on global liquidity standards. The two new liquidity ratios, the short-term liquidity coverage ratio and the longer-term net stable funding ratio, oblige banks to increase their high-quality liquid assets and obtain more short-term sources of funding. In the context of this paper, these further restrictions could discourage banks from investing in long-term infrastructure projects. According to the UK National Infrastructure Plan (HM Treasury, 2016), companies that operate in regulated price regimes (such as rail and aviation) will be less impacted by this regulation; for these companies generally, long-term financing will remain as a viable option through the municipal bond market. However, other infrastructures may have a much more difficult environment looming for future investment. There is, however, a new transition underway towards the so-called plain vanilla financial instruments; these can be traded in more liquid and conventional markets using standardised contracts. This transition represents an important change in the development of financial sources for local authorities to dedicate to infrastructure investments and will be the topic of the next section.

\section{Collective solution for infrastructure: local authority finance}

Local government funding agencies in countries such as France, Holland, Japan, New Zealand and Canada are in the process of issuing bonds that provide loans at competitive rates for local authorities to invest in infrastructure. The NLFGA is surely the forerunner of these organisations. The NLFGA facilitates co-operation among four agencies: Kommunalbanken (Norway), KommuneKredit (Denmark), Kommuninvest (Sweden) and Municipality Finance (Finland), and their issue is equal to US\$35-40 billion annually in bonds, notes and commercial papers. The four agencies act as debt offices and providers of costefficient financing for their respective local authorities and companies owned by local authorities, which include, but are not limited to, the provision of housing, energy supply, transport and communications. The local authorities of these four countries have a long tradition of highly decentralised governance, and one such manifestation is the right and capacity of the local governments in each of these countries to levy taxes and user fees to fund their own activities of health care, education and transport.

The fiscal administration and regime of Nordic local authorities is one of the main drivers behind the security and creditworthiness of the four local authority finance agencies. Another important aspect is membership; in all four countries, the majority of the local authorities (municipalities and counties) have joined the agencies. In Sweden, of the 290 municipalities and 20 county councils, Kommuninvest accounts for 275 municipalities and 11 county councils. In Finland, 328 municipalities (corresponding to $99 \%$ of the total population) belong to the society underpinning the Finnish Municipality Finance. This large membership base has allowed them to reduce the municipal financial cost; for example, in Sweden since the start date of 1986, the agency has helped reduce their financing costs by SEK 300 million (SEK $1=\mathrm{US} \$ 36.52$ ), approximately the equivalent of $£ 26.5$ million (Kommuninvest, 2013). By early 2016, the society had reached a total year lending of SEK 277 billion, a value which had increased year by year and was given the highest credit rating possible by both S\&P Global Ratings and Moody's (Kommuninvest, 2016). The dedicated participation by local authorities in the specific agencies has had a positive impact on the credit market, which views the specific agencies in the same way as do the Norwegian, Swedish, Danish and Finnish states, respectively. The other positive aspect of this unity of agencies relates to their capacity to operate efficiently and to compete with the capital markets.

In order to lend to local authorities, the Kommuninvest of Sweden's Funding Programme raises funds through short- and long-term borrowing programmes on the national and international capital markets. Most of the borrowing is secured by bonds and commercial papers; only a small proportion of the borrowing of the agency is in the form of direct loan financing. The long-term ambition is for the bond programme to become the largest of the agency. The larger volume of lending is mainly explained by increased lending to municipal corporations. In 2016, the Swedish local government loan market grew from SEK 20 billion to SEK 568 billion, growth that is mostly the result of a steady pace of investment within the local government authorities and municipal companies. Of the local government sector's total borrowing, $44 \%$ has been financed through Kommuninvest (Kommuninvest, 2016).

A similar agency known as the Municipal Bond Agency (MBA) was launched in the UK in 2016. UK local authorities typically borrow and refinance between $£ 3-5$ billion annually, and in 2016, they had an outstanding debt of approximately $£ 85$ billion (Cobley, 2016). The Public Works Loan Board (PWLB), the main government lending agency, has implemented a low (approximately $0 \cdot 8 \%$ ) interest rate on loans to principal local authorities. The MBA handles $75 \%$ of the loans to local authorities. Although at present, only a small percentage of British local authorities have signed onto the scheme, and no issuances have taken place, there is the expectation in the financial market that the MBA will provide competitive issuances in relation to the PWLB with some frequency and will include the possibility of selecting assets.

One significant element in the debate on the development of similar agencies in other European countries is the creditworthiness of the agencies. Andersson (2012) has claimed that the crucial question of credit enhancement can be solved by adopting a system of cross-guarantees with final liability to the local authority that borrows from the agency. 'The conclusion is that cross-guarantees are an efficient way to assure a good credit 
rating for the agency and that it could be done without excessive risk taking' (Andersson, 2012: p. 23).

Some European local authorities have nevertheless issued municipal bonds without having to garner the support of a national agency. An illustrative case is the issuance of municipal bonds by the Romanian city of Oradea. The city issued its first municipal bond in 2003 worth 10 million Romanian Leu (1 Romanian Leu $=$ US\$0.27), immediately followed by another bond issue worth 15 million Romanian Leu. Both issues were directed to transport redevelopment investments in Oradea. The city authorities have guaranteed the principal repayments and interest from the two bond issues through their power vested in the local fiscal system in an agreement signed by the mayor. In 2008 , the ratings agency Fitch assigned a B + rating to the city of Oradea for long-term debt in foreign currency, and a B in shortterm debt. Different from the Nordic countries' case, this rating was based on Romania's highly centralised budget control system in which the state approves and supervises debt contracts, thereby ensuring effective guarantees and a positive interpretation of the rating.

As the present paper has made clear, the success of bond issuance by local authorities to finance infrastructure investments is inextricably linked with the context and the authorities/agencies from which they are issued. Moreover, it is important to keep in mind that default risks may often be associated with broad macroeconomic trends and processes. However, in pleading the municipal bond's case, an insightful comparative study conducted for the city of Oradea concluded that although the cheapest source of finance for the city was the loan provided by the European Investment Bank, in relation to the internal bank - that is, the Romanian Commercial Bank - the municipal bonds issued by the city were much more convenient (Bunescu, 2010).

Every country will have its own economic circumstances, as Walker (2012) observed in his article, 'Painting the town red'. When the Spanish local authority of Valencia delayed payments on a loan and, as a consequence, Standard and Poor's downgraded Valencia to a BB/B rating on the edge of 'junk' status, the bond markets trembled. However, the resurgence of interest in municipal bonds arising after the banking and financial crisis verifies that municipal bonds are indeed a feasible funding source for infrastructure investments.

\section{Conclusion and policy recommendations}

The present paper has demonstrated that bonds can be and indeed are implemented in effective ways to finance major infrastructure investments. Municipal bonds in particular can certainly be one local authority strategy in the financing and funding of infrastructure projects and public capital improvements. Great flexibility is built into the bond structure, which allows for targeting, and thus tailoring incentives, risk-sharing and guarantee mechanisms. The two most common bond structures described here (GO and revenue) are bonds pegged at the fiscal system and bonds pegged at the return flows from the infrastructures. The type of bond selected must be decided on the basis of context and how it corresponds to the aims that the infrastructure investment can realistically achieve (certainly in the short run), but particularly with regard to long-term economic growth. In this context, private finance can be leveraged as infrastructure investments generate returns, and effective public debt through municipal bonds can reinforce the creditworthiness of a local authority, such as a city, along with the value of the infrastructure assets themselves. Moreover, as observed by Bailey et al. (2009), municipal bonds can act as tools to foster devolving and decentralisation policies, but importantly too, they can also serve to increase financial capability within local authorities, with the ultimate aim to instil greater responsibility and understanding of local financial decision-making with regard to infrastructure investment.

However, it is also problematic that infrastructures with often long-term return horizons nevertheless suffer from the 'lock-in' effect - that is, the chosen technological solutions may not align with the requirements of future trends and developments of the municipalities or regions in question. The result could be utter failure from different perspectives, but particularly from the financial point of view because the relationship between type of infrastructure investment and success of the bond(s) issued by local authorities is direct: as one begins to fail, the other(s) follows suit. Although local authorities have the advantage of being able to separate revenues from expenditures, they are often political entities. Therefore, in times of financial distress, they may be more inclined to prioritise the provision of essential services rather than pay bond holders (Moody's, 2017). Indeed, political and regulatory risks will have to be reduced for financing infrastructures because they can no longer be considered as barriers to investment. Therefore, it is incumbent on governments to build long-term frameworks for infrastructure development, particularly for investments with environmental objectives.

Increasingly, local authorities need to be globally competitive, and in order to maintain their competitive edge, they must unlock investment through the use of innovative financial and business models: the bond market offers a viable means of achieving this aim.

\section{REFERENCES}

Ahfeldt GM and Feddersen A (2010) From Periphery to Core: Economic Adjustments to High Speed Rail. London School of Economics, London, UK; University of Hamburg, Hamburg, Germany.

Allen G (2001) The Private Finance Initiative. House of Commons Library, London, UK, Research Paper 01/117.

Andersson LM (2012) Are Cross-Guarantees Dangerous? New Local Government Network, London, UK, Report NLGN.

Appleson J, Parson E and Haughwout A (2012) The Untold Story of Municipal Bond Defaults. Federal Reserve Bank, New York, NY, USA. Assemblée Nationale (2011) Rapports d'Information Publies. Assemblée Nationale, Paris, France (in French).

Baldwin R, Forslid R, Ottaviano G and Robert-Nicoud F (2005) Economic Geography and Public Policy. Princeton University Press, New York, NY, USA. 
Bailey SJ, Asenova D and Hood J (2009) Making widespread use of municipal bonds in Scotland. Public Money and Management 29(1): 11-18. Berkooz CB (2014) The BOND rating game. Planning 80(3): 25-29. BIS (Bank for International Settlements) (2010) Basel III: A Global Regulatory Framework for More Resilient Banks and Banking Systems. Bank for International Settlements, Basel, Switzerland.

Blenkinsop P and Laurent L (2011) UPDATE - Dexia agrees to FrancoBelgian rescue deal. Reuters, 10 October.

Boarnet MG (2014) National transportation planning: Lessons from the US Interstate Highways. Transport Policy 31: 73-82.

Bunescu L (2010) Municipal bonds: a viable funding option for Oradea local public administration: economic analysis working paper. Atlantic Review of Economics 9: 1-15.

Chen Y, Li F and Wang H (2013) Study on urban infrastructure bottlenecks. In Proceedings of the International Conference on Information Engineering and Applications (IEA) 2012 (Zhong Z (ed.)). Springer-Verlag, London, UK, vol. 5, pp. 119-125.

Ciccarone R (2010) Tax-backed bonds and federal intervention, reform and influence over municipal market. The National Federation of Municipal Analysts Advanced Seminar, 11-12 February, Palm Beach, FL, USA.

Cobley M (2016) UK's local government expenditures. Financial News, 7 November: p. A6.

Decker M (2017) America's Infrastructure: The Time to Build Is Now. Sifma, New York, NY, USA.

Edwards C (2013) Encouraging Private Infrastructure Investment. Cato Institute, Washington, DC, USA.

Feldstein SG and Fabozzi FJ (2008) The Handbook of Municipal Bonds. Wiley, Hoboken, NJ, USA

FMDV (Global Fund for Cities Development) (2014) Resolutions Europe: Local Innovations to Finance Cities and Regions. FMDV, Paris, France.

France in the United Kingdom (2012) Dexia Bank - Reply by François Fillon, Prime Minister, to a Question in the National Assembly (Excerpts). French Embassy Press Office, London, UK. See https://uk. ambafrance.org/French-local-authorities-to-be (accessed 17/05/2018).

FSA (Financial Services Authority) (2012) Setting the Scene: Standard Formula and USPs. FSA, London, UK.

Green RC, Hollifield B and Schürhoff N (2007) Dealer intermediation and price behaviour in the aftermarket of new bond issues. Journal of Financial Economics 86(3): 643-682.
HM Treasury (2016) National Infrastructure Delivery Plan: 2016-2021. HM Treasury, London, UK.

Infrastructure USA (2017) http://www.infrastructureusa.org (accessed 27/03/2018)

Inspiratia (2010) Basel III and Infrastructure Investments. Inspiratia, London, UK.

Investing Bonds Europe (2013) http://www.investingbondseurope.org (accessed 16/05/2017).

Kalotay A (2014) The interest rate sensitivity of tax-exempt bonds under tax-neutral valuation. Journal of Investment Management 12(1): $62-68$.

Kommuninvest (2013) Annual Report 2013. Kommuninvest Cooperative Society, Orebro, Sweden.

Kommuninvest (2016) Annual Report 2016. Kommuninvest Cooperative Society, Orebro, Sweden.

Liu G (2012) Municipal bond insurance premium, credit rating, and underlying credit risk. Public Budget and Finance 32(1): 128-156.

McCarthy KE and Hansen LR (2013) Clean Energy Finance and Investment Authority Initiatives. Office of Legislative Research, Connecticut General Assembly, Hartford, CT, USA, OLR Research Report 2013-R-0175.

Medda F (2012) Land value capture finance for transport accessibility: a review. Journal of Transport Geography (25): 154-161.

Moody's (2017) US Municipal Bond: Defaults and Recoveries, 1970-2016. Moody's, New York, NY, USA, Data report.

Morgenson G and Story L (2011) Bank's collapse in Europe points to global risks. The New York Times, 23 October.

Novethic (2013) Green and Social Bonds: A Promising Tool. Novethic Research, Paris, France.

Sifma (Securities Industries and Financial Markets Association) (2012) The Fundamentals of Municipal Bonds, 6th edn. Wiley, Hoboken, NJ, USA.

Sifma (2017) US Municipal Credit Report. Sifma, New York, NY, USA. United Cities and Local Governments (2017) Sustainable Territorial and Local Development. Cities Alliance, Barcelona, Spain.

United Cities and Local Governments (2013) UCLG Policy Paper on Local Finance. Cities Alliance, Barcelona, Spain.

Walker D (2012) Painting the Town Red. Public Finance International, London, UK, AP.1.

\section{How can you contribute?}

To discuss this paper, please email up to 500 words to the editor at journals@ice.org.uk. Your contribution will be forwarded to the author(s) for a reply and, if considered appropriate by the editorial board, it will be published as discussion in a future issue of the journal.

Proceedings journals rely entirely on contributions from the civil engineering profession (and allied disciplines). Information about how to submit your paper online is available at www.icevirtuallibrary.com/page/authors, where you will also find detailed author guidelines. 